\title{
MODEL PEMBELAJARAN SYNECTICS UNTUK PENINGKATAN KEAKTIFAN DAN HASIL BELAJAR KIMIA
}

\author{
Sri Purwanti \\ SMK Negeri 1 Pleret \\ Sripurwanti068@gmail.com
}

\begin{abstract}
Abstrak: Permasalahan pencapaian keaktifan dan hasil belajar siswa dalam pembelajaran kimia di kelas X Teknik Jaringan Tenaga Listrik (TJTL) di SMKN 1 Pleret belum sesuai yang diharapkan. Dalam penelitian ini bertujuan untuk mengetahui peningkatan keaktifan dan hasil belajar kimia melalui model pembelajaran Synectics yang meliputi 3 aspek, yaitu aspek kognitif, afektif, dan psikomotor. Jenis penelitian ini adalah penelitian tindakan kelas yang berlangsung 2 siklus, masing masing siklus terdiri dari 4 tahap yaitu perencanaan, tindakan, observasi dan refleksi. Subyek penelitiannya adalah siswa kelas X TJTL dengan jumlah 36 siswa laki-laki. Teknik pengumpulan data berupa tes dan non tes, dan analisa data deskriptif kuantitatif dan kualitatif .Hasil penelitian menunjukkan bahwa penggunaan model pembelajaran synectics dapat meningkatkan keaktifan dan hasil belajar siswa. Dari data diperoleh peningkatan keaktifan sebesar $25,40 \%$ siswa sangat aktif 63,89\% di siklus 1 menjadi 89,29\% di siklus 2. Sedangkan dari data hasil belajar siswa diperoleh data siswa KKM di prasiklus $14,86 \%$, siklus 1adalah $61,11 \%$ dan siklus 2 adalah 88,89\%. Atau mengalami kenaikan 46,25\% dari prasiklus ke siklus 1, dan peningkatan 27,78\% dari siklus 1 ke siklus 2.
\end{abstract}

Kata kunci: Model Pembelajaran Synectics, Keaktifan, dan Hasil belajar.

\section{SYNECTICS LEARNING MODEL TO INCREASE THE ACTIVITY AND LEARNING OUTCOMES OF CHEMISTRY}

\begin{abstract}
The problem of achieving student learning outcomes and activeness in learning chemistry in Kelas X Teknik Jaringan Tenaga Listrik (TJTL) in SMKN 1 Pleret has not been as expected. In this study, the aim of this research is to find out how to increase the activity and learning outcomes of chemistry through the Synectics learning model which includes 3 aspects, namely cognitive, affective, and psychomotor aspects. This type of research is a classroom action research that lasts 2 cycles, each cycle consisting of 4 stages, namely planning, action, observation and reflection. The research subjects were students of class X TJTL with a total of 36 male students. Data collection techniques in the form of tests and non-tests, and descriptive quantitative and qualitative data analysis. The results showed that the use of synectics learning models can increase student activity and learning outcomes. From the data obtained an increase in activeness of $25.40 \%$, the students were very active $63.89 \%$ in cycle 1 to $89.29 \%$ in cycle 2. While the data on student learning outcomes obtained data on KKM students in pre-cycle $14.86 \%$, cycle 1 was $61,11 \%$ and cycle 2 is $88.89 \%$. Or an increase of $46.25 \%$ from pre-cycle to cycle 1, and an increase of $27.78 \%$ from cycle 1 to cycle 2.
\end{abstract}

Keywords: Synectics Learning Model, Activeness, and Learning Outcomes.

\section{PENDAHULUAN}

Pendidikan menjadi sarana utama yang perlu dikelola secara sistematis dan konsisten berdasarkan berbagai pandangan teori dan praktik yang berkembang dalam kehidupan. Semakin tinggi cita-cita manusia, semakin menuntut tingkat mutu pendidikan sebagai sarana mencapai cita-citanya (Rusmini, 2011:1).

Pengaruh pembelajaran aktif terhadap peningkatan hasil belajar telah dilaporkan dalam beberapa penelitian. Bonwell dan Eison (1991) menelaah beberapa literatur tentang pembelajaran aktif, dan menyimpulkan bahwa pembelajaran aktif akan memperbaiki sikap siswa, dan meningkatkan kemampuan siswa dalam berpikir dan menulis. Bonwell dan Eison menyatakan bahwa belajar aktif dapat didefinisikan sebagai metode pembelajaran yang melibatkan siswa dalam proses belajar. Belajar secara aktif mengharuskan siswa untuk melakukan aktifitas belajar yang bermakna dan memikirkan tentang apa yang mereka lakukan.

Berdasarkan hasil ulangan harian siswa kelas X Teknik Jaringan Tenaga Listrik (TJTL) di SMKN 1 Pleret tampak bahwa prestasi 
belajar siswa belum optimal, hal ini ditunjukkan dengan nilai yang KKM yaitu 5 dari 36 siswa atau sekitar 13,86\%. Untuk itu perlu dilakukan upaya memperbaiki kualitas proses pembelajaran melalui suatu tindakan yang dapat meningkatkan prestasi belajar yang lebih baik yang ditandai dengan $80 \%$ siswa memenuhi KKM atau sebanyak 28 siswa yang nilainya diatas KKM.

Seorang guru harus mampu menerapkan, memilih suatu strategi pembelajaran yang tepat sehingga mampu memecahkan permasalahan pembelajaran yang optimal ( Made Wina : 2018). Salah satu alternatif untuk mengatasi masalah prestasi dan kualitas pembelajaran adalah dengan menerapkan model pembelajaran synectics.

Menurut Agus Supriyono (2016), Model sinektiks berorientasi pada pengembangan pribadi dan keunikan individu, diutamakan dalam membentuk dan mengorganisasikan realita yang unik. Kelebihan lain model ini adalah lebih banyak memperhatikan kehidupan emosional peserta didik. Sinektiks dirancang untuk membimbing guru masuk dalam dunia yang hampir tidak masuk akal untuk memberikan kepadanya kesempatan menciptakan cara baru dalam memandang sesuatu, mengekspresikan diri dan mendekati permasalahan. Sinektiks berarti strategi mempertemukan berbagai macam unsur, dengan menggunakan kiasan untuk memperoleh satu pandangan baru. Selanjutnya model sinektiks berorientasi meningkatkan kemampuan pemecahan masalah, ekspresi kreatif, empati dan wawasan dalam hubungan sosial.

Beberapa kelebihan model pembelajaran sinektiks adalah: 1) peserta dapat mengembangkan kejelasan pengertian dan internalisasi pada diri peserta didik tentang materi baru, 2) menciptakan suasana kebebasan intelektual dan kesamaan martabat antar paserta didik, 3) mengembangkan berpikir kreatif, 4) membantu peserta didik menemukan cara berpikir baru untuk memecahkan masalah, 5) peserta didik terlibat aktif dalam pembelajaran, 6) melatih berpikir sistemik, 7) meningkatkan keseluruhan aspek yang berkaitan dengan ketrampilan menulis, 8) mengembangkan pengertian baru tentang suatu masalah sehingga peserta didik sadar bagaimana seharusnya bertingkah laku dalam situasi tertentu.

Beberapa kekurangan yang dimiliki model pembelajaran sinektiks adalah: 1) tidak bisa diterapkan untuk semua jenjang sekolah dasar, 2) membutuhkan waktu yang lama untuk beradaptasi belajar mandiri, 3) membutuhkan lingkungan belajar memadai, 4) sulit dilaksanakan bagi guru dan peserta didik yang sudah terbiasa dengan pembelajaran ekspositori, 5) menitikberatkan pada berpikir reflektif dan imajinatif dalam situasi tertentu.

Tujuan Penelitian ini untuk:1) Mengetahui peningkatan keaktifan belajar kimia melalui model pembelajaran Synektiks pada siswa SMKN 1 Pleret pada semester genap tahun pelajaran 2019/2020. 2)Mengetahui peningkatan hasil belajar kimia melalui model pembelajaran Synektiks pada siswa di SMKN 1 Pleret pada semester genap tahun pelajaran 2019/2020.

\section{METODE PENELITIAN}

Subyek penelitian adalah siswa kelas $\mathrm{X}$ TJTL ( Teknik Jaringan Tenaga Listrik) yang berjumlah 35 siswa dengan jenis kelamin semuanya laki laki pada materi pembelajaran Hidrokarbon dan Minyak Bumi. Tempat pelaksanaan penelitian di ruang kelas, ruang laboratorium dan di halaman sekolah. Penelitian ini dilakukan dengan dibantu kolaborator untuk menjadi observer dan sebagai pater diskusi

\section{Prosedur Pelaksanaan Penelitian}

Pelaksanaan penelitian dilaksanakan dalam 2 siklus, dengan langkah-langkah: 1) Perencanaan: Tahap perencanaan meliputi: Pembuatan silabus, pembuatan RPP, membuat lembar observasi, Lembar kerja siswa (LKS), lembar pengamatan guru dan siswa, membersiapkan alat alat pembelajaran, dan alat evaluasi. 2) Tindakan: Tindakan dilakukan oleh peneliti sebagai upaya membangun pemahaman konsep siswa. Dalam tindakan ini menerapkan model pembelajaran Sinektiks sesuai RPP yang sudah disiapkan meliputi 2 siklus, dan masing masing siklus 2 pertemuan dan setiap pertemuan 3 jam pelajaran. 3) Observasi : Kolaborator mengamati dampak dari diterapkannya model Sinektiks yang dituliskan di lembar observasi tentang keaktifan siswa dan kinerja guru serta didokumentasikan baik melalui foto maupun video. Guru atau peneliti mencatat dan mengamati semua kegiatan yang dialami siswa setiap tahap dalam pembelajaran pada saat mulai tindakan sampai evaluasi. 4) Refleksi: Peneliti mengkaji, melihat dan mempertimbangkan hasil dari tindakan yang dilakukan berdasarkan foto, video dan lembar pengamatan yang sudah ditulis 
oleh kolaborator. Dari hasil pengamatan dan observasi dididskusikan dengan kolaborator, baik dari lembar pengamatan keaktifan siswa maupun kinerja guru/ peneliti dalam tindakan tersebut. Hasil refleksi dipakai sebagai bahan untuk menentukan langkah pada siklus 2. 5) Membuat rencana yang sudah direvisi berdasarkan hasil refleksi untuk siklus berikutnya.

\section{HASIL DAN PEMBAHASAN}

Pada bab ini berisi tentang deskripsi kondisi pra siklus, deskripsi siklus 1, deskripsi siklus 2 dan deskripsi antar silus. Masing masing siklus terdiri dari 4 tahap yaitu perencanaan, pelaksanaan tindakan, observasi dan refleksi.

Pembahasan Hasil penelitian siklus 1 dan siklus 2 adalah sebagai berikut:

Hasil observasi/pengamatan aspek sikap keaktifan siswa pada siklus 1 dan siklus 2 terlihat dalam tabel berikut ini:

1. Hasil Belajar siswa pada aspek sikap/ afektif

Hasil belajar siswa pada aspek afektif pada kedua siklus dapat dilihat pada tabel berikut.

Tabel 1. Keaktifan siswa aspek sikap / afektif pada siklus 1 dan siklus 2

\begin{tabular}{ccc}
\multirow{2}{*}{ Kategori } & \multicolumn{2}{c}{ Keaktifan Siswa } \\
\cline { 2 - 3 } & $\begin{array}{c}\text { Prosentase } \\
\text { siklus 1 }\end{array}$ & $\begin{array}{c}\text { Prosentase } \\
\text { siklus 2 }\end{array}$ \\
\hline Kurang Aktif & 41,67 & - \\
Aktif & 77,93 & 66,67 \\
Sangat Aktif & 63,89 & 89,29 \\
\hline
\end{tabular}

Pada tabel 1 di atas, siklus 1 terlihat bahwa prosentase siswa yang kurang aktif adalah $41,67 \%$, siswa yang aktif $77,93 \%$, dan sangat aktif $63,89 \%$. Dalam hal ini terjadi perubahan pada siklus 2. Pada siklus 2 tidak ditemukan lagi siswa yang kurang aktif, sedangkan pada siswa aktif berkurang menjadi $66,67 \%$ dari $77,93 \%$, dan siswa yang sangat aktif terjadi peningkatan menjadi $89,29 \%$ dari $63,89 \%$ atau meningkat sebanyak $25,40 \%$.

Jika dalam bentuk grafik terlihat bahwa perbandingan antara siklus 1 dengan warna biru dan siklus 2 dengan warna orange dalam gambar berikut:

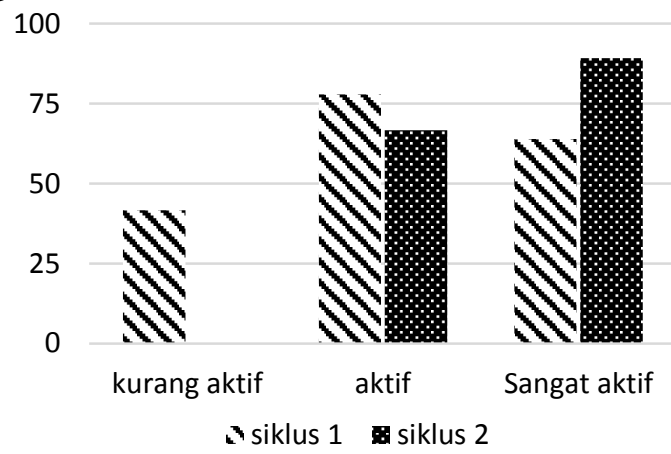

Gambar 1. Diagram keaktifan Siswa pada Aspek Afektif

2. Hasil belajar siswa pada aspek Kognitif siklus 1 dan 2

Hasil belajar siswa pada aspek kognitif pada kedua siklus dapat dilihat pada tabel berikut.

Tabel 2. Hasil Belajar Siswa / aspek kognitif pada siklus 1 dan siklus 2

\begin{tabular}{|c|c|c|c|c|c|}
\hline \multirow{3}{*}{ Deskripsi } & \multicolumn{4}{|c|}{ Ketercapaian hasil Belajar aspek Kognitif } & \multirow{3}{*}{ Kenaikan } \\
\hline & \multicolumn{2}{|c|}{ Siklus 1} & \multicolumn{2}{|c|}{ Siklus 2} & \\
\hline & KKM & Tidak & KKM & Tidak & \\
\hline Jumlah Siswa & 22 & 14 & 32 & 4 & 10 \\
\hline Prosentase & $61,11 \%$ & $38,89 \%$ & $88,89 \%$ & $11,11 \%$ & $27,78 \%$ \\
\hline
\end{tabular}

Pada tabel 2: menunjukkan data hasil belajar siswa aspek kognitif atau pengetahuan yang dibuat berdasarkan hasil evaluasi tertulis pada akhir siklus 1 dan siklus 2. Dalam data tersebut terlihat bahwa jumlah siswa yang KKM pada siklus 1 adalah 22 orang, yang belum KKM 14 orang dari 36 jumlah siswa. Sedangkan pada siklus 2 terjadi peningkatan menjadi $32 \mathrm{KKM}$ atau meningkat 10 orang. Jumlah yang belum KKM menurun dari dari 14 siswa menjadi 4 siswaatau turun 10 orang. Kalau dibuat prosentase jumlah yang KKM meningkat $27,78 \%$ dari $61,11 \%$ pada siklus 1 menjadi $88,89 \%$ pada siklus 2 . Atau mengalami penurunan pada siswa yang belum KKM , adri
$38,89 \%$ pada siklus 1 menurun menjadi $11,11 \%$ pada siklus 2. Jika digambarkan dengan grafik diagram terlihat pada gambar 2 berikut ini:

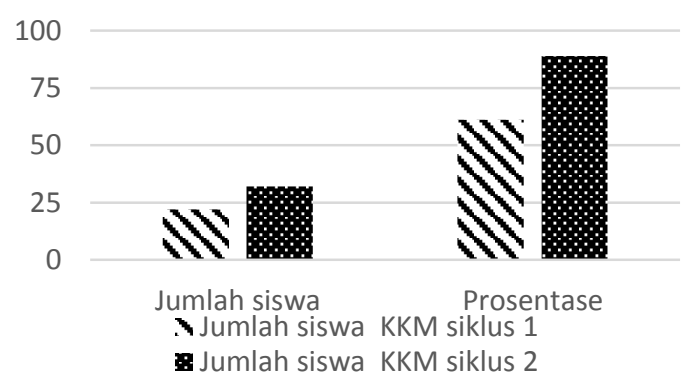

Gambar 2. Diagram Hasil Belajar Siswa pada Aspek Kognitif 


\section{Aspek Psikomotorik/ Ketrampilan}

Tabel 3. Hasil ketercapaian Ketrampilan/Aspek psikomotorik

\begin{tabular}{ccc}
\hline \multirow{2}{*}{ Deskripsi } & \multicolumn{2}{c}{ Ketercapaian Ketrampilan } \\
& \multicolumn{2}{c}{ Aspek Psikomotorik } \\
\cline { 2 - 3 } & Siklus 1 & Siklus 2 \\
Kritera & Cukup baik & Baik \\
Prosentase & $68,06 \%$ & $70,76 \%$ \\
\hline
\end{tabular}

Berdasarkan pengamatan psikomotor dari guru sebagai peneliti diperoleh data bahwa ketrampilan siswa dalam merangkaikan struktur molekul menggunakan molymod dan dalam unjuk kerja atau presentasi terjadi kenaikan rata rata dari $68,06 \%$ di siklus 1 menjadi $70,76 \%$ di siklus 2 . Atau mengalami kenaikan 2,70\%. Dengan kategori cukup baik pada siklus 1 menjadi kategori baik pada siklus 2. Hal ini tampak juga dalam gambar diagram 3 berikut:

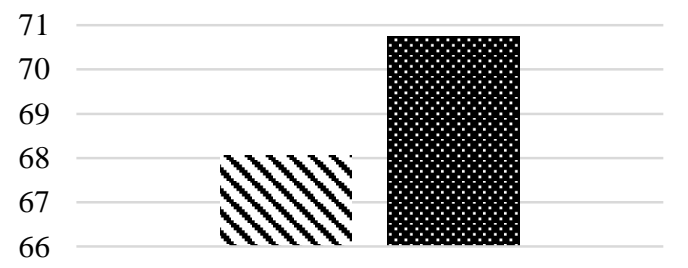

Prosentase

Siklus 1 Siklus 2

Gambar 3. Diagram Hasil Belajar siswa pada Aspek Psikomotor

Pada penelitian ini membuktikan bahwa penggunakan model pembelajaran sinektiks yang dikembangkan untuk meningkatkan berpikir kreatif, dan untuk menciptakan kelas menjadi suatu masyarakat intelektual yang menyediakan berbagai kesempatan bagi peserta didik bertindak kreatif dan menjelajahi gagasan gagasan baru dalam bidang ilmu pengetahuan alam, teknologi, dan seni sangat sesuai dan relevan pada materi kimia di SMK terutama pada materi Hidrokarbon dan Minyak bumi karena disamping dapat meningkatkan hasil belajar di bidang kognitif/ pengetahuan juga dapat meningkatkan ketrampilan / psikomotor siswa dalam menganalogikan bentuk bentuk molekul yang abstrak dengan menggunakan model atom molymod dan plastisin yang dirangkai sedemikian rupa sehingga dapat menggambarkan rangkaian model atom dalam senyawa hidrokarbon tersebut.

Pada penelitian ini juga sangat sesuai dengan model pembelajaran sinektiks yang dikembangkan William JJ Gordonn bertumpu pada pemikiran: a) Kreativitas sangat penting dalam kehidupan sehari hari, oleh karena itu model ini dirancang untuk meningkatkan kemampuan seseorang memecahkan masalah, mengekspresikan sesuatu secara kreatif, menunjukkan empati, dan memiliki wawasan sosial, b) Proses kreativitas bukanlah hal misterius, proses ini dapat melatih seseorang secara langsung sehingga dapat meningkatkan kreativitasnya, c) Penemuan yang kreatif hakekatnya sama dalam berbagai bidang dan ditandai oleh proses intelektual yang melatar belakangi, d) Penemuan yang kreatif dari individu dan kelompok pada dasarnya serupa. Individu dan kelompok membangkitkan ide dan hasil dalam bentuk yang serupa. Hal ini dibuktikan dengan adanya partisipasi dan keikutsertaan para siswa dalam kegiatan berkelompok untuk memecahkan masalah menemukan alternatif solusi dan menyampaikan gagasan dalam presentasi dan unjuk kerja .

Dalam pelaksanannya, model sinektiks melibatkan penggunaan metafora atau analogi melalui perbandingan sebuah objek gagasan dengan objek gagasan lain. Melalui aktivitas metafora, dalam model sinektiks kreativitas menjadi proses yang dapat dijalankan secara sadar. Selain menggunakan aktivitas metafora, model sinektiks juga menggunakan analogi untuk menghasilkan gagasan kreatif atau wawasan segar ke dalam permasalahan. Dalam pembelajaran ini peneliti menggunakan bantuan vidio sebagai gambaran di awal untuk apersepsi dan motivasi siswa dalam mengikuti pelajaran.

Peran guru dalam model pembelajaran sinektiks sebagai prinsip reaksi adalah mendorong keterbukaan dan ekspresi kreatif dari peserta didik, memperagakan jika perlu. Guru menerima seluruh respons peserta didik dan memilih analogi analogi yang membantu peserta didik untuk berfikir.Hal ini ditunjukkan dengan pendampingan dan pembimbingan selama diskusi, pemilihan kelompok diskusi yang harus dipertimbangkan antara siswa yang punya kemampuan dan siswa yang kurang berkemampuan supaya diskusi dapat berjalan dengan baik.

Sistem pendukung adalah peserta didik tetap membutuhkan fasilitas dari seorang guru yang kompeten dalam merancang dan menerapkan prosedur prosedur analisis. Peserta didik juga memerlukan sebuah laboratorium yang dapat membangun model model dan perangkat perangkat lain untuk menjadikan 
masalah semakin konkret. Dalam hal ini perlu peran serta sekolah dalam mendukung keberhasilan pembelajaran seperti buku buka pelajaran, LCD , dan televisi untuk pembelajaran serta alat alat peraga lainnya, misalnya model atom molymod, bahan plastisin, dan lain lain.

Syntaks dalam model pembelajaran sinektiks terdiri dari 6 tahap. Tahap pertama , mendeskripsikan kondisi saat ini. Guru meminta peserta didik mendeskripsikan situasi suatu topik yang mereka lihat saat itu. Pada tahap pertama ini peneliti memberikan tayangan contoh senyawa hidrokarbon yang ada disekitar siswa. Dalam vidio tersebut juga memperlihatkan praktikum yang bisa dilihat siswa karena sekolah tidak bisa melaksanakan praktikum tersebut, bahan dan alat praktek kurang lengkap sehingga praktikum tidak bisa dilaksanakan di sekilah. Siswa sangat antusias dan memperhatikan tayangan tersebut meskipun pelaksanaannya di perpustakaan.

Tahap kedua, analogi langsung. Peserta didik mengemukakan analogi langsung, salah satu diseleksinya dan selanjutnya dikembangkan. Pada pembelajaran dengan materi Hidrokarbon dan Minyak Bumi ini siswa mengajukan beberapa usulan, dan diseleksi bersama dengan teman kelompoknya. Untuk mengembangkannya diperlukan masukan dari guru pendamping yang sekiranya dapat dilaksanakan dalam proses pembelajaran. Dalam hal ini pentingnya guru dalam membentuk kelompok yang merata dalam kompetensinya sehingga diskusi dapat berjalan lancar.

Tahap ketiga, analogi personal. Para peserta didik menganalogikan sesuatu yang diseleksinya pada fase kedua. Pada tahap ini diperlukan praktek untuk melihat ketrampilan dan unjuk kerja masing masing siswa. Guru mendampingi siswa untuk membantu dan mengarahkan siswa dalam menganalogikan suatu masalah.

Tahap keempat, konflik padat. Berdasarkan fase kedua dan ketiga para peserta didik mengemukakan beberapa konflik dan dipilih salah satu dari konflik tersebut. Hasil dari tahap ini dipresentasikan dikelompok masing masing sebagai bahan untuk presentasi kelas dan hasil dari unjuk kerja.

Tahap kelima, analogi langsung. Para peserta didik mengembangkan dan menyeleksi analogi langsung lainnya berdasarkan konflik tadi. Dari hasil presentasi diperoleh masukan dari teman temannya dan guru pendamping. Siswa dapat mengembangkan analogi nya dengan kehidupan di sekitar rumah masing masing.

Tahap keenam, meninjau tugas yang sebenarnya. Guru meminta para peserta didik meninjau kembali tugas atau masalah yang sebenarnya dan menggunakan analogi yang terakhir dan atau masuk pada pengalaman sinektis. Guru memberikan tugas dan mengevaluasi hasil dari diskusi dan presentasi yang telah dilakukan siswa.

Dari keenam tahap tersebut , tahap kedua merupakan tahap yang dituntut untuk kreatif dalam memilih analogi baik siswa maupun gurunya. Dalam hal ini perlu referensi dan pegetahuan awal yang dimiliki siswa yang bisa menjadi pengalaman bermakna dalam belajar siswa.

\section{SIMPULAN DAN SARAN}

Berdasarkan hasil penelitian dan pembahasan di bab IV, maka dapat disimpulkan sebagai berikut:1) Pembelajara menggunakan model synektiks pada materi Hidrokarbon dan Minyak bumi pada peserta didik kelas X TJTL di SMKN 1 Pleret Bantul semester genap tahun pelajaran 2019/2020 dapat meningkatkan keaktifan belajar siswa. Pada siklus 1 dengan prosentase 63,89\% meningkat menjadi $89,29 \%$ pada siklus 2 atau meningkat 25,40 \% dengan kategori sangat aktif. Prosentase ketrampilan siswa terjadi kenaikan rata rata dari 68,06 \% dengan ankategori cukup baik di siklus 1 menjadi 70,76 $\%$ dengan kategori baik di siklus 2. Atau mengalami kenaikan 2,70\%. 2) Pembelajaran model Synektiks pada pembelajaran hidrokarbon dan minyak bumi untuk siswa kelas X TJTL semester genap di SMKN 1 Pleret Bantul tahun pelajaran 2019/2020 dapat meningkatkan hasil belajar siswa. Prosentase ketuntasan siswa meningkat dari $14,86 \%$ di pra siklus, $61,11 \%$ pada siklus 1 menjadi $88,89 \%$ pada siklus 2 .

\section{DAFTAR PUSTAKA}

Agus Wasisto Dwi Doso warso, M. P. (2016). PKB Publikasi Ilmiah Penelitian tindakan kelas (PTK) dan Nilai Angka Kreditnya. Yogyakarta: Pustaka Pelajar.

Djudin, T. (2011). Mendekati makna kreativitas dan model pembelajaran synectics. Jurnal Pendidikan Matematika dan IPA, 8-11. 
- (2013). model pembelajaran synectics: suatu tawaran mengembangkan kreativitas siswa melalui pembelajaran sains. Jurnal pendidikan informatika dan sains, 1-2.

Muhaultani Taufik, M. K. (2018). Pengaruh model pembelajaran synectics, mind maps, cooperative learning (SM2CL) terhadap kemampuan berfikir kritis siswa. jurnal biotek, 1-2.

Mustami, M. K. (2015). Model SM2CL untuk pembelajaran biologi yang inovatif. jurnal biotek, 1-3.

Nur alia, t. t. (2016). efektifitas perbandingan model pembelajaran synectics dengan model konvensional (ceramah) terhadap kemampuan berpikir kreatif siswa. jurnal biotek, 1-2.

Parwoto. (2010). Model Pembelajaran Synectics dengan media komputer untuk peningkatan berfikir kreatif siswa berbakat di SD. Indonesian Journal of Educational Studies, 1-2.

Sani, R. A. (2019). Strategi Belajar Mengajar. Depok: Rajawali Pers.

Suprijono, A. (2016). Model - model Pembelajaran Emansipatoris. Yogyakarta: Pustaka Pelajar.

Susanti, L. (2019). Prestasi Belajar Akademik dan Non Akademik. Malang: Literasi Nusantara.

Susanto, E. B. (2013). PTK. Yogyakarta: Liberty.

Wihardit, I. W. (2010). Penelitian Tindakan Kelas. Jakarta: Universitas Terbuka.

Wina, M. (2018). Strategi Pembelajaran Inovatif Kontenporer. Jakarta: PT Bumi Aksara. 